\title{
Lhermitte sign and myelopathy after irradiation of the cervical spinal cord in radiotherapy treatment of head and neck cancer
}

Citation for published version (APA):

Mul, V. E. M., de Jong, J. M. A., Murrer, L. H. P., van den Ende, P. L. A., Houben, R. M. A., Lacko, M., Lambin, P., \& Baumert, B. G. (2012). Lhermitte sign and myelopathy after irradiation of the cervical spinal cord in radiotherapy treatment of head and neck cancer. Strahlentherapie Und onkologie, 188(1), 71-76. https://doi.org/10.1007/s00066-011-0010-2

Document status and date:

Published: 01/01/2012

DOI:

10.1007/s00066-011-0010-2

Document Version:

Publisher's PDF, also known as Version of record

Document license:

Taverne

Please check the document version of this publication:

- A submitted manuscript is the version of the article upon submission and before peer-review. There can be important differences between the submitted version and the official published version of record.

People interested in the research are advised to contact the author for the final version of the publication, or visit the DOI to the publisher's website.

- The final author version and the galley proof are versions of the publication after peer review.

- The final published version features the final layout of the paper including the volume, issue and page numbers.

Link to publication

\footnotetext{
General rights rights.

- You may freely distribute the URL identifying the publication in the public portal. please follow below link for the End User Agreement:

www.umlib.nl/taverne-license

Take down policy

If you believe that this document breaches copyright please contact us at:

repository@maastrichtuniversity.nl

providing details and we will investigate your claim.
}

Copyright and moral rights for the publications made accessible in the public portal are retained by the authors and/or other copyright owners and it is a condition of accessing publications that users recognise and abide by the legal requirements associated with these

- Users may download and print one copy of any publication from the public portal for the purpose of private study or research.

- You may not further distribute the material or use it for any profit-making activity or commercial gain

If the publication is distributed under the terms of Article $25 \mathrm{fa}$ of the Dutch Copyright Act, indicated by the "Taverne" license above, 
Strahlenther Onkol 2012 • 188:71-76

DOI 10.1007/s00066-011-0010-2

Received: 20 May 2011

Accepted: 15 September 2011

Published online: 23 December 2011

(c) Springer-Verlag 2011

V.E.M. Mul ${ }^{1,3}$ - J.M.A. de Jong ${ }^{1}$ - L.H.P. Murrer ${ }^{1}$ P.L.A. van den Ende ${ }^{1}$.

R.M.A. Houben ${ }^{1} \cdot$ M. Lacko ${ }^{2}$ P. Lambin ${ }^{1}$ - B.G. Baumert ${ }^{1}$

${ }^{1}$ Dept Radiation-Oncology (MAASTRO), GROW (School for Oncology \& Developmental

Biology), Maastricht University Medical Centre (MUMC), Maastricht

2 Dept Otorhinolaryngology and Head and Neck Surgery, Maastricht

University Medical Centre (MUMC), Maastricht

${ }^{3}$ Dept Radiation-Oncology, University Medical Center Groningen

(UMCG)/ University of Groningen, Groningen

\section{Lhermitte sign and myelopathy after irradiation of the cervical spinal cord in radiotherapy treatment of head and neck cancer}

er these data are applicable for currently used modern radiotherapy techniques such as intensity modulated radiotherapy (IMRT) [14, 19]. A recent review reasoned that it is not possible to draw firm conclusions as data are limited due to the small number of patients developing myelopathy [22].

Chronic progressive radiation myelopathy (CPRM) can be preceded by delayed onset of Lhermitte sign (LS; 9-15 months after radiotherapy treatment) $[6,10,12$, $20,28,32]$. LS is a transient myelopathy with shock-like sensations from the neck to the extremities, typically after flexion of the neck, and can be evoked by different factors including radiotherapy $[2,21$, $27,30]$.
Although radiation damage to the spinal cord can result in LS and rarely in CPRM, not much is known about these phenomena. Neither the tolerance dose of the spinal cord nor the shape of the dose-volume curve is established. This study was performed to examine potential clinical risk factors, maximum dose, and dose-volume distribution of the spinal cord in relation to LS and CPRM in patients irradiated for head and neck cancer at one institute.

\section{Patients and methods}

The study was approved by the local Institutional Review Board of MAASTRO clinic according to the Dutch legislation. where three-dimensional (3D) planning was not yet standard. It is doubtful wheth-

\section{Tab. 1 Scoring systems for Lhermitte sign (LS) and myelopathy}

\begin{tabular}{|c|c|c|c|c|c|c|}
\hline LS & 0 & 1 & 2 & 3 & 4 & 5 \\
\hline $\begin{array}{l}\text { CTCAE } \\
\text { v3.0 }\end{array}$ & & $\begin{array}{l}\text { Asymptomatic/mild } \\
\text { signs(Lhermitte's sign) }\end{array}$ & $\begin{array}{l}\text { Weakness or sensory loss } \\
\text { not interfering with ADL }\end{array}$ & $\begin{array}{l}\text { Weakness or sensory loss inter- } \\
\text { fering with ADL }\end{array}$ & Disabling & Death \\
\hline $\begin{array}{l}\text { RTOG/ } \\
\text { EORTC }\end{array}$ & None & $\begin{array}{l}\text { Mild Lhermitte syn- } \\
\text { drome }\end{array}$ & $\begin{array}{l}\text { Severe Lhermitte syn- } \\
\text { drome }\end{array}$ & $\begin{array}{l}\text { Objective neurological findings } \\
\text { at or below the level treated }\end{array}$ & $\begin{array}{l}\text { Mono-, para-, or } \\
\text { quadriplegia }\end{array}$ & $\begin{array}{l}\text { Death directly } \\
\text { related to radiation } \\
\text { late effects }\end{array}$ \\
\hline CMS & 0 & 1 & 2 & 3 & 4 & 5 \\
\hline $\begin{array}{l}\text { Upper ex- } \\
\text { tremity }\end{array}$ & Intact & $\begin{array}{l}\text { Sensory symptoms } \\
\text { only }\end{array}$ & $\begin{array}{l}\text { Mild motor deficit with } \\
\text { some functional impair- } \\
\text { ment }\end{array}$ & $\begin{array}{l}\text { Major functional impairment } \\
\text { in at least one upper extremity } \\
\text { but upper extremities useful } \\
\text { for simple tasks }\end{array}$ & $\begin{array}{l}\text { No movement or } \\
\text { flicker of movement } \\
\text { in upper extremities; } \\
\text { no useful function }\end{array}$ & \\
\hline $\begin{array}{l}\text { Lower ex- } \\
\text { tremity }\end{array}$ & Intact & $\begin{array}{l}\text { Walks independently } \\
\text { but not normally }\end{array}$ & $\begin{array}{l}\text { Walks but needs cane or } \\
\text { walker }\end{array}$ & Stands but cannot walk & $\begin{array}{l}\text { Slight movement but } \\
\text { cannot walk or stand }\end{array}$ & Paralysis \\
\hline
\end{tabular}

CTCAE Common Terminology Criteria for Adverse Events version 3.0, RTOG Radiation Therapy Oncology Group, EORTC European Organization for Research and Treatment of Cancer, ADL activities of daily life, CMS Cooper Myelopathy Scale. 


\begin{tabular}{|c|c|c|c|c|}
\hline Parameter & Attribute & $\begin{array}{l}\text { LS } \\
\text { (17 patients) }\end{array}$ & $\begin{array}{l}\text { No-LS } \\
\text { (420 patients) }\end{array}$ & $\begin{array}{l}\text { p val- } \\
\text { ue }\end{array}$ \\
\hline $\begin{array}{l}\text { Follow-up } \\
\text { (months) }\end{array}$ & Median (range) & $56(17-126)$ & $26(1-126)$ & 0.001 \\
\hline Age (years) & Median (range) & $52(44-64)$ & $61(35-91)$ & 0.001 \\
\hline \multirow[t]{2}{*}{ Gender } & Male & 12 & 311 & \multirow[t]{2}{*}{ n.s. } \\
\hline & Female & 5 & 109 & \\
\hline \multirow[t]{3}{*}{ Diagnosis } & cT2-4N0-3M0 laryngeal carcinoma & 11 & 203 & \multirow[t]{3}{*}{ n.a. } \\
\hline & $\begin{array}{l}\text { cT1-4N0-3M0 oropharyngeal car- } \\
\text { cinoma }\end{array}$ & 5 & 127 & \\
\hline & $\begin{array}{l}\text { Other (oral/nasal cavity, hypophar- } \\
\text { ynx) }\end{array}$ & 1 & 90 & \\
\hline \multirow[t]{2}{*}{ Surgery } & Yes & 3 & 107 & \multirow[t]{2}{*}{ n.s. } \\
\hline & No & 14 & 313 & \\
\hline \multirow{2}{*}{$\begin{array}{l}\text { Diabetes mel- } \\
\text { litus }\end{array}$} & Yes & 0 & 47 & \multirow[t]{2}{*}{ n.s. } \\
\hline & No & 17 & 373 & \\
\hline \multirow[t]{2}{*}{ Hypertension } & Yes & 2 & 94 & \multirow[t]{2}{*}{ n.s. } \\
\hline & No & 15 & 326 & \\
\hline \multirow{2}{*}{$\begin{array}{l}\text { Cardiovascular } \\
\text { disease }\end{array}$} & Yes & 5 & 146 & \multirow[t]{2}{*}{ n.s. } \\
\hline & No & 12 & 274 & \\
\hline \multirow{3}{*}{$\begin{array}{l}\text { Radiation tech- } \\
\text { nique }\end{array}$} & Half beam with direct junction & 0 & 19 & \multirow[t]{3}{*}{ n.s. } \\
\hline & IMRT & 1 & 39 & \\
\hline & Other non-IMRT techniques & 16 & 362 & \\
\hline \multirow{2}{*}{$\begin{array}{l}\text { Neoadjuvant } \\
\text { chemotherapy }\end{array}$} & Yes & 0 & 15 & \multirow[t]{2}{*}{ n.s. } \\
\hline & No & 17 & 405 & \\
\hline \multirow{2}{*}{$\begin{array}{l}\text { Concomitant } \\
\text { chemotherapy }\end{array}$} & Yes & 1 & 26 & \multirow[t]{2}{*}{ n.s. } \\
\hline & No & 16 & 394 & \\
\hline \multirow[t]{2}{*}{ Fraction size } & $\leq 2 \mathrm{~Gy}$ & 17 & 389 & \multirow[t]{2}{*}{ n.s. } \\
\hline & $>2 \mathrm{~Gy}$ & 0 & 31 & \\
\hline \multirow{2}{*}{$\begin{array}{l}\text { Accelerated ra- } \\
\text { diotherapy }^{\mathrm{a}}\end{array}$} & Yes & 12 & 189 & \multirow[t]{2}{*}{0.047} \\
\hline & No & 5 & 231 & \\
\hline \multirow{3}{*}{$\begin{array}{l}\text { Prescribed tu- } \\
\text { mor dose }\end{array}$} & $\leq 55 \mathrm{~Gy}$ & 0 & 27 & \multirow[t]{3}{*}{ n.s. } \\
\hline & $>55-<68 \mathrm{~Gy}$ & 0 & 34 & \\
\hline & $\geq 68 \mathrm{~Gy}$ & 17 & 359 & \\
\hline
\end{tabular}

LS Lhermitte sign, Max maximum, PRV planning organ volume at risk, SCA spinal cord area, SC spinal cord, SCP3, SCP5 Spinal cord-PRV (3 or $5 \mathrm{~mm}$ margin), RT radiotherapy, AP anterior-posterior, OTT overall treatment time, n.s. not significant, n.a. not available ${ }^{a}$ Accelerated radiotherapy: 68 Gy, two times daily for 11 fractions (in 2 Gy fractions, OTT 38 days).

\section{Tab. 3 Dose-volume data and LS}

\begin{tabular}{|c|c|c|c|c|}
\hline $\begin{array}{l}\text { Lhermitte } \\
\text { sign }\end{array}$ & $\begin{array}{l}\text { SCA: } \\
\text { volume } \geq 45 \text { Gy } \\
\text { (median, SD; range) }^{a}\end{array}$ & $\begin{array}{l}\text { SCP3: } \\
\text { volume } \geq 50 \text { Gy } \\
\text { (median, SD; }^{\text {range) }}{ }^{a}\end{array}$ & $\begin{array}{l}\text { SCP3: } \\
\text { volume } \geq 52 \text { Gy } \\
\text { (median, SD; }^{\text {range) }}{ }^{a}\end{array}$ & $\begin{array}{l}\text { SCP3: } \\
\text { volume } \geq 54 \text { Gy } \\
\text { (median, SD; } \\
\text { range) }{ }^{a}\end{array}$ \\
\hline Yes & $\begin{array}{l}14.15 \\
(3.66 ; 12.4-20.7)\end{array}$ & $\begin{array}{l}0.06 \\
(0.7 ; 0-2.2)\end{array}$ & $\begin{array}{l}0 \\
(0.48 ; 0-1.6)\end{array}$ & $\begin{array}{l}0 \\
(0.24 ; 0-0.8)\end{array}$ \\
\hline No & $\begin{array}{l}7.9 \\
(7.68 ; 0-43.1)\end{array}$ & $\begin{array}{l}0.9 \\
(5.71 ; 0-33)\end{array}$ & $\begin{array}{l}0.2 \\
(4.05 ; 0-28.5)\end{array}$ & $\begin{array}{l}0.06 \\
(3.09 ; 0-23.0)\end{array}$ \\
\hline$p$ value & 0.042 & 0.024 & 0.012 & 0.018 \\
\hline$\Sigma$ & $8.2(0-43.1)$ & $0.8(0-33)$ & $0.2(0-28.5)$ & $0.05(0-23.0)$ \\
\hline
\end{tabular}

LS Lhermitte sign, SCA spinal cord area, SC spinal cord, SD standard deviation; for IMRT: SCP3 spinal cord-PRV (3 mm margin) aMedian values, standard deviation and range for the spinal cord volumes are noted in $\mathrm{cm}^{3}$.
Patient population and treatment indication

Of 489 patients treated for head and neck tumors between January 1997 and December 2007, 437 patients with the spinal cord in the radiation field were eligible. Postoperative radiotherapy was applied to 110 patients and 327 patients primary radiotherapy. Chemotherapy was given to $9.6 \%$ of patients: $6.2 \%$ as concomitant chemotherapy and $3.4 \%$ in a neoadjuvant setting as part of a trial. Palliative radiotherapy treatment had 33 patients $(7.6 \%)$, and patients were re-irradiated for relapse.

Primary radiotherapy consisted of treatment of the primary tumor and bilateral neck regions up to $46 \mathrm{~Gy}$, followed by a boost to the primary tumor and macroscopic nodes up to 68-70 Gy twice daily for 11 fractions (1.8 Gy per fraction with an interval $>6 \mathrm{~h}$, overall treatment time 38 days). Postoperative radiation doses ranged from 46-70 Gy depending on the estimated risk of recurrence [24]. For palliation, locoregional radiotherapy with $30-39$ Gy in fractions of 3 Gy was applied (37.5-48.8 Gy equivalent dose for fractions of $2 \mathrm{~Gy}\left(\mathrm{EQD}_{2}\right)$, linear quadratic with $\alpha / \beta=2 \mathrm{~Gy})$.

\section{Radiotherapy treatment planning}

All patients had an individual mask in the treatment position. Radiotherapy was applied in several phases where the spinal cord was shielded from radiation in the second phase after 46 Gy. After introduction of CT-based planning in 1996, "poor man's" IMRT based on compensators was developed. Modern IMRT started in 2006. Since 2005 , in vivo dosimetry is routinely performed for all curative treatments. Accordingly, over time different parameters for spinal cord contouring have been used: (1) simulation with the spinal cord area (SCA) defined as the anatomical area between the osseous borders of vertebrae and the anterior part of the processes spinosus, (2) CT-based contouring of the spinal cord (SC), (3) spinal cord in combination with a spinal cord planning organ at risk volume with a margin of $3 \mathrm{~mm}$ (SCP3), and (4) a margin of $5 \mathrm{~mm}$ (SCP5) for IMRT. 
Planning was performed according to ICRU 62 [18]. Earlier the dose-volume histogram (DVH) calculation did not take into account the additional electron boost. The DVH was coarsely adjusted to correct the maximum spinal cord dose for the boost dose. If the distance between the spinal cord and the edge of the radiation field was more than $7 \mathrm{~mm}$, the DVH was not adjusted, because the dose contribution to the spinal cord was thought to be negligible. Different scaling factors of DVHs were corrected by visual estimation when the DVH curve asymptotically approached the dose axis.

\section{Follow-up}

Follow-up consisted of regular visits to the head and neck oncology department during 5 years after curative radiotherapy with the medical history taken and physical examination done. Imaging, pathology, and referral to a neurologist were performed if indicated. After primary radiotherapy, a PET-CT scan (since 2003) was obtained 3 months after treatment. Toxicity was assessed by the CTCAE v3.0 score for myelitis, the RTOG/EORTC score for late morbidity to the spinal cord $[7,8,35]$, and the Cooper Myelopathy Scale (• Tab. 1).

\section{Statistical analysis}

All analyses were performed with SPSS 15.0. Due to the small number of events, only descriptive and univariate analyses were possible. The largely unequal sample size between comparison groups and the non-normal distribution of the data warranted that differences in continuous independent factors were tested with the Mann-Whitney U test. Differences in frequency distributions of nominal or ordinal factors were tested with the $\chi^{2}$ test. Follow-up time was calculated from the day after ending of radiotherapy until death or last follow-up. Patients who had a relapse and were retreated with RT were not censored for LS or myelopathy. All patients (437) were included for the analysis of clinical data. Dose-volume data were available for 387 patients (88.6\%). Clinical data and DVH data per contouring group (SCA, SC, and SCP3 or SCP5) were analyzed as risk factors for myelopathy.

Strahlenther Onkol 2012 · 188:71-76 DOI 10.1007/s00066-011-0010-2

(C) Springer-Verlag 2011

V.E.M. Mul • J.M.A. de Jong · L.H.P. Murrer · P.L.A. van den Ende · R.M.A. Houben · M. Lacko • P. Lambin · B.G. Baumert

\section{Lhermitte sign and myelopathy after irradiation of the cervical spinal cord in radiotherapy treatment of head and neck cancer}

\section{Abstract}

Background and purpose. The goal of this work was to examine toxicity and risk factors after irradiation of the cervical spinal cord. Patients and methods. A total of $437 \mathrm{pa}$ tients irradiated for a laryngeal and oropharyngeal carcinoma were eligible (median follow-up 27 months). Spinal cord contouring was defined differently over time as anatomically defined spinal cord area (SCA) and the spinal cord on CT (SC) with a margin of 3 or $5 \mathrm{~mm}$ (SCP3/SCP5).

Results. None developed chronic progressive radiation myelopathy (CPRM) (maximum spinal dose $21.8-69 \mathrm{~Gy}) ; 3.9 \%$ (17/437) developed a Lhermitte sign (LS) with a median duration of 6 months (range 1-30 months) and was reversible in all patients. Risk factors for developing LS were younger age ( $52 \mathrm{vs.}$ 61 years, $p<0.001)$, accelerated RT (12/17 patients, $p<0.005)$, and dose-volume relationships for SCA with $\geq 45$ Gy of $14.15 \mathrm{~cm}^{3}$ and $7.9 \mathrm{~cm}^{3}$ for patients with and without LS, respectively.

Conclusion. LS is more frequently observed in younger patients and in patients treated with accelerated radiotherapy. A dose-volume relationship was seen for $\mathrm{V} 45$ in the case of SCA. For higher doses, no clear dose-volume relationships were observed.

\section{Keywords}

Spinal cord tolerance - Lhermitte sign . Chronic progressive radiation myelopathy . Radiotherapy · Head and neck cancer

\section{Lhermitte-Zeichen und Myelopathie nach Bestrahlung des zervikalen Rückenmarks bei Strahlentherapie von Kopf-Hals- Tumoren}

\section{Zusammenfassung}

Hintergrund und Ziel. Untersuchung von Toxizität und Risikofaktoren nach Bestrahlung des zervikalen Rückenmarks.

Patienten und Methoden. Daten von 437 Patienten mit einem Larynx- oder Oropharynxkarzinom wurden untersucht (mediane Nachbeobachtungszeit 27 Monate). Die Rückenmarkkonturierung veränderte sich im Laufe der Zeit: zuerst anatomisch definiert (SCA), später CT-basiert (SC) mit einem Sicherheitssaum von 3 oder $5 \mathrm{~mm}$ (SCP3/ SCP5).

Ergebnisse. Es wurde keine progressive radiogene Myelopathie (CPRM) beobachtet (max. Myelondosis 21,8-69,0 Gy); 3,9\% (17/437 Patienten) entwickelten ein Lhermitte-Zeichen (LS) mit einer medianen Dauer von 6 Monaten (1-30 Monaten), das bei allen Patienten reversibel war. Risikofaktoren für die Entwicklung des LS waren jüngeres Alter (52 vs. 61 Jahre, $p<0,001$ ), akzelerierte RT (12/17 Patienten; $p<0,005)$ ( $\quad$ Tab. 2) und Dosis-Volumen-Beziehungen für SCA von $\geq 45$ Gy für $>14,15 \mathrm{~cm}^{3}$ versus $7,9 \mathrm{~cm}^{3}$ (• Tab. 3, - Fig. 1).

Schlussfolgerungen. LS wird häufiger bei jüngeren Patienten und nach akzelerierter Strahlentherapie gesehen. Eine Dosis-Volumen-Beziehung wurde bei der SCA für das V45 dokumentiert. Für höhere Bestrahlungsdosen wurden keine Dosis-Volumen-Beziehungen dokumentiert.

\section{Schlüsselwörter}

Rückenmarktoleranz - Lhermitte-Zeichen . Chronische progressive radiogene Myelopathie · Strahlentherapie .

Kopf- und Halstumoren

\section{Results}

The median follow-up was 27 months (range 1-126 months). For patient and treatment characteristics see $\bullet$ Tab. 2. No chronic myelopathy (CPRM) was observed with a median dose of $50 \mathrm{~Gy}$ (max. spinal dose 21.8-69 Gy) to the spinal cord.
Lhermitte sign: onset time and duration

LS occurred in 17 of the 437 patients (3.9\%; RTOG/EORTC: 14 grade 1 and 3 grade 2; CTCAE scores: 16 grade 1 and 1 grade 2 ). The median maximum dose to the spinal cord was 48.7 Gy (range 38.2$58.6 \mathrm{~Gy})$. The risk to develop LS was $2.5 \%$, 


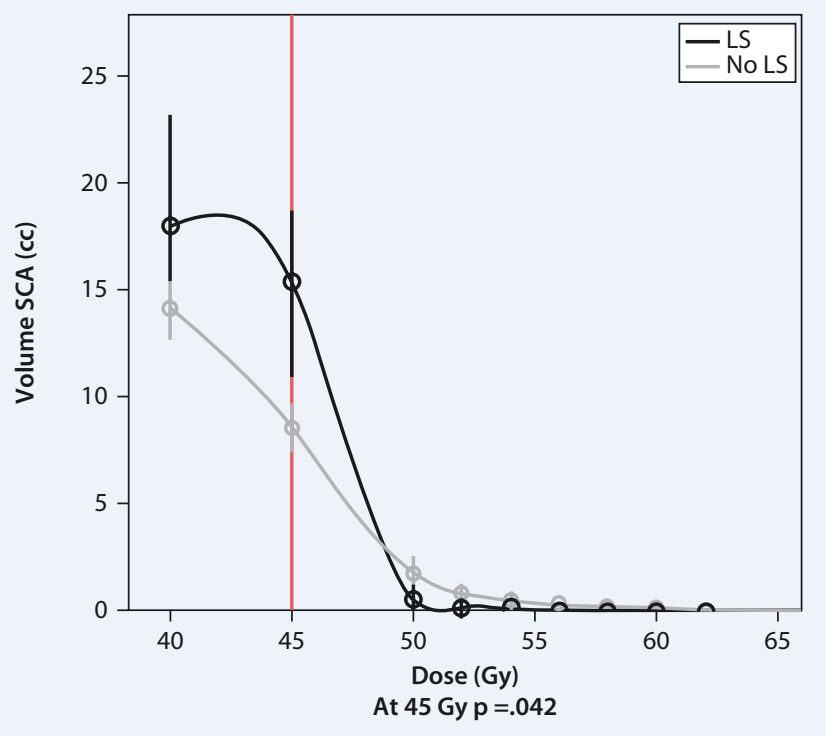

Fig. $1<$ Dose-volume relationship for anatomically defined spinal cord area (SCA) and Lhermitte sign $(L S)$. The vertical line represents significant difference in irradiated volumes and dose. Error bars show $95 \%$ confidence interval of the mean

$3.7 \%$, and $3.9 \%$ at 3,6 , and 12 months, respectively. The median onset time for LS in the entire group was 3 months (range 1-10 months). The median duration of LS was 6 months (range 1-30 months). There was no significant difference for onset time and duration between grades 1 and 2. None of 7 patients re-irradiated for relapse with the spinal cord in the radiotherapy treatment field with a prescribed mean dose of 52.7 Gy developed LS.

\section{Imaging and treatment}

In 3 of 17 patients with LS (17.6\%), imaging was obtained at the time of LS symptoms. A MRI scan showed no changes of demyelinization in 2 patients. A PET-CT scan in the third patient showed no abnormalities with regard to the spinal cord. Three patients were referred to a neurologist. One of these patients was treated with corticosteroids, but treatment was stopped due to side effects.

\section{Risk factors}

Age was a significant prognostic factor. Patients developing LS were younger (median 52 years; - Tab. 2). Twelve out of 17 had accelerated radiotherapy. Occurrence of LS was evenly distributed over time (1997: 1; 1998: 2; 2000 and 2001: 1; 2002 and 2003: 3; 2005: 4; 2006: 2 patients). The median maximum dose and the maximum dose to the spinal cord were higher for the non-LS group, but not sigin the SCP5 and SC group developed LS.

\section{Dose-volume relationship LS}

A significant difference in irradiated volumes at specific dose levels was found in 3 out of 4 spinal cord contouring groups: LS was seen for larger volumes at lower dose ( $\geq 45 \mathrm{~Gy}$ ) and small volumes with doses of $\geq 50$ Gy (• Tab. 3, • Fig. 1). For all patients independent of the contouring group, the median volume receiving doses of $\geq 45$ Gy and $\geq 50$ Gy were $11 \mathrm{~cm}^{3}$ (LS patients $16.6 \mathrm{~cm}^{3}$, non-LS $10.8 \mathrm{~cm}^{3}$, not significant) and $0.3 \mathrm{~cm}^{3}$ (LS $0.04 \mathrm{~cm}^{3}$, nonLS $0.3 \mathrm{~cm}^{3}$, not significant), respectively. For the SCA group, spinal cord volumes irradiated to a dose $\geq 50$ Gy were median $0 \mathrm{~cm}^{3}$ for both LS and non-LS patients, and 0.06 and $0.90 \mathrm{~cm}^{3}$, respectively, for LS and non-LS patients of the SCP3 group.

\section{Discussion}

The occurrence rate of LS due to irradiation of cervical spinal cord is reported as $3.6 \%$ [15] which we could confirm with our results of $3.9 \%$. The median time until occurrence is 3 months with a median duration of 6 months (longest duration $>1$ year). Similar time frames have been reported with onset 1-6 months after radiotherapy and spontaneous regression after 2-9 months $[6,10,20,21,26]$. The median follow-up time for patients with a LS was significantly shorter due to the fact nificantly different. None of the patients that patients were included until the study cut-off date. This is, however, acceptable, because the onset of LS was observed as early as 1 month.

The lowest spinal cord dose related to LS was described at dose levels of $29 \mathrm{~Gy}$ and $36.52 \mathrm{~Gy}$, which is comparable to $38.2 \mathrm{~Gy}$ in our study [20]. We found a slightly lower dose of 48.7 Gy compared to a reported dose of $\geq 50$ Gy to the cervical cord described as being significant for developing LS [15]. Significantly more LS were reported if daily fractions were $\geq 2$ Gy [15] which we cannot confirm as all patients with LS were irradiated with a fraction size $\leq 2 \mathrm{~Gy}$. However, for patients irradiated with accelerated radiotherapy twice daily during the last week, a significant correlation was seen. LS was observed in 12/17 patients treated by accelerated RT two times daily 1.8 Gy with an interval of $>6 \mathrm{~h}$ during the last week. These findings are supported in the literature where a LS incidence of $3.9 \%$ was reported for accelerated schedules using fraction sizes of $1.2 \mathrm{~Gy}$ [15].

The incidence of LS was equally distributed over the years of our observation period from 1997-2007, parallel to the stepwise introduction of modern radiotherapy techniques and the use of online dosimetry. Radiation techniques do not seem to have influenced the number of events.

Another potential risk factor investigated was dose-volume relation. Significant dose-volume relationships with larger volumes of $14.15 \mathrm{~cm}^{3}$ and a dose $\geq 45 \mathrm{~Gy}$ were observed when anatomically defined contouring of the spinal cord was used. If CT-based contouring with or without a margin of $3 \mathrm{~mm}$ is used, very small volumes of $0-0.06 \mathrm{~cm}^{3}$ containing higher dose areas of $\geq 50$ Gy constitute a risk. This seems logical, because non-CT based definition of the spinal cord results automatically in larger irradiated volumes of the spinal cord. However, CT-based contouring with an added margin of $5 \mathrm{~mm}$ has not yet resulted in LS due to the small patient numbers $(n=3)$, like in the recent literature [16]. It is remarkable that the difference between LS and no LS is not observed in the high dose areas: non-LS patients had received higher maximum doses (not significant) and V50-54 at larger median volumes (significant) than LS patients. The median volumes of the SCP3 
group were all $<1 \mathrm{~cm}^{3}$ and, therefore, probably too small to be consistently treated: due to the mobility of the spinal cord despite mask mobilization. The maximum spinal cord dose in a very small volume is, thus, likely to be blurred. Inoue et al. [17] report on 1 patient with $\mathrm{D}_{0.5 \mathrm{~cm} 3}$ of $127 \mathrm{~Gy}$ $\left(\mathrm{BED}_{2}\right)$ to the cervical spine with a transient myelitis, however, after re-irradiation [17]. To our knowledge, no dose-volume response data of the spinal cord with regard to LS are known in the literature.

Patients developing LS were significantly younger (52 versus 61 years) which is in concordance with the study of Leung et al. [26] who reported a lower incidence of LS $(2.8 \%)$ in patients with an age of 60 years or older.

On MRI and PET imaging, no changes potentially corresponding with LS were observed in our patients imaged. Esik et al. [13] reported 2 patients with chronic LS after radiotherapy where the MRI did not reveal any pathological signs of demyelination. A FDG-PET scan showed an increased FDG uptake in the irradiated spinal cord. Lengyel et al. [25] presented a patient with a partially recovering radiation myelopathy: repeated PET scans revealed increased FDG and $\mathrm{O}^{15}$ butanol uptake with no $\mathrm{C}^{11}$ methionine accumulation in the irradiated spinal cord. At autopsy axonal and neuronal loss with little vascular changes, inflammation, or proliferation was seen.

The occurrence rate of CPRM due to irradiation of the cervical spinal cord with $46.6-60$ Gy is reported to range from $0.18-$ $1.9 \%$ [29, 31]. Determining factors for myelopathy reported were the integral irradiated spinal cord volume, the dose distribution in the spinal cord, and influence of bath dose highest for a $2 \mathrm{~mm}$ field and absent for $8 \mathrm{~mm}$ fields $[3,4,5]$. Recovery of CPRM is estimated as being 61\% [1]. A recent review estimated the risk of myelopathy at total doses of $50 \mathrm{~Gy}, 60 \mathrm{~Gy}$, and ca. 69 Gy as $0.2 \%, 6 \%$, and $50 \%$ using fractions of 1.8-2 Gy [22]. We observed no CPRM despite irradiation of the spinal cord to high doses of 69 and 60 Gy with a median follow-up of 27 months and 15 months, respectively. The median dose to the spinal cord was about 50 Gy which is often reported in the literature as a cut-off point for an acceptable dose to the spinal cord.
Patients with a spinal cord dose of at least 50 Gy had a significantly shorter follow-up, but both groups had an equal percentage of follow-up of $\geq 10$ months which is about the latest onset time for LS in our group and, thus, too short to observe CPRM. The reason for this is most presumably the fact that patients with a higher dose to the spinal cord often had larger tumors and it was deemed acceptable to irradiate the spinal cord to a higher dose than $50 \mathrm{~Gy}$ in order to ensure good tumor coverage.

LS due to radiotherapy treatment seems to be a different biological entity than CPRM. First, LS is usually reversible. Only late onset LS may develop into CPRM [6, 10, 12, 20, 28, 32]. Second, LS developed at maximum doses as low as 38.2 Gy. Third, demyelination of axons by radiotherapy leads to reduced speed of action potentials. This can be resolved by a higher sodium channel density, but this causes increased glucose metabolism and, therefore, greater tissue perfusion. Increased FDG and $\mathrm{O}^{15}$ butanol uptake as well autopsy findings with lack of structural damage of LS patients support this view $[12,13]$.

\section{Conclusion}

Development of LS was observed in 17 of 437 patients (3.9\%) with no chronic progressive radiation myelopathy. Among clinical risk factors, only a younger age (median 52 versus 61 years) and the application of accelerated RT were identified as being significantly associated with LS. The treatment technique was not a risk factor. Median volume of $14.15 \mathrm{~cm}^{3}$ of the spinal cord area receiving a total dose of at least $45 \mathrm{~Gy}$ (V45 Gy) was a risk factor for development of LS. For higher doses, no clear dose-volume relationship can be confirmed as volumes at risk were very small.

\section{Corresponding address}

\section{Dr. B.G. Baumert}

Dept Radiation-Oncology (MAASTRO), GROW

(School for Oncology \& Developmental Biology), Maastricht University Medical Centre (MUMC)

Dr. Tanslaan 12, 6229 ET Maastricht

The Netherlands

brigitta.baumert@maastro.nl
Acknowledgement. We thank Elisabeth H.J.A. Dekkers, MSc, for providing the medical records and her overall assistance and the Department of Radiation Oncology (MAASTRO), the Netherlands.

Conflict of interest. The corresponding author states that there are no conflicts of interest.

\section{References}

1. Ang KK, Jiang GL, Feng $Y$ et al (2001) Extent and kinetics of recovery of occult spinal cord injury. Int J Radiat Oncol Biol Phys 50:1013-1020

2. Babinski J, Dubois R (1918) Douleurs a forme de decharge électrique, consecutives aux traumatismes de la nuque. Presse Med 26:64

3. Bijl HP, Luijk P van, Coppes RP et al (2003) Unexpected changes of rat cervical spinal cord tolerance caused by inhomogeneous dose distributions. Int J Radiat Oncol Biol Phys 57:274-281

4. Bijl HP, Luijk P van, Coppes RP et al (2002) Dosevolume effects in the rat cervical spinal cord after proton irradiation. Int J Radiat Oncol Biol Phys 52:205-211

5. Bijl HP, Luijk P van, Coppes RP et al (2006) Influence of adjacent low-dose fields on tolerance to high doses of protons in rat cervical spinal cord. Int J Radiat Oncol Biol Phys 64:1204-1210

6. Boden G (1948) Radiation myelitis of the cervical spinal cord. Br J Radiol 21:464-469

7. Common Terminology Criteria for Adverse Events v3.0 (CTCAE). Cancer Therapy Evaluation Program, Common Terminology Criteria for Adverse Events, Version 3.0, DCTD, NCl, NIH, DHHS; March 31, 2003. http://ctep.cancer.gov. Publish Date: August 9, 2006

8. Cox JD, Stetz J, Pajak TF (1995) Toxicity criteria of the Radiation Therapy Oncology Group (RTOG) and the European Organization for Research and Treatment of Cancer (EORTC). Int J Radiat Oncol Biol Phys 31:1341-1346

9. Dische S, Saunders MI (1989) Continuous, hyperfractionated, accelerated radiotherapy (CHART): an interim report upon late morbidity. Radiother Oncol 16:65-72

10. Dynes JB, Smedal MI (1960) Radiation myelitis. Am J Roentgenol Radium Ther Nucl Med 83:78-87

11. Emami B, Lyman J, Brown A et al (1991) Tolerance of normal tissue to therapeutic irradiation. Int J Radiat Oncol Biol Phys 21:109-122

12. Esik O, Csere T, Stefanits K et al (2003) Increased metabolic activity in the spinal cord of patients with long-standing Lhermitte's sign. Strahlenther Onkol 179:690-693

13. Esik O, Csere T, Stefanits K et al (2003) A review on radiogenic Lhermitte's sign. Pathol Oncol Res 9:115-120

14. Farrag A, Voordeckers M, Tournel K et al (2010) Pattern of failure after helical tomotherapy in head and neck cancer. Strahlenther Onkol 186:511-516

15. Fein DA, Marcus RB Jr, Parsons JT et al (1993) Lhermitte's sign: incidence and treatment variables influencing risk after irradiation of the cervical spinal cord. Int J Radiat Oncol Biol Phys 27:1029-1033

16. Gunn GB, Endres EJ, Parker B et al (2010) A phase I/II study of altered fractionated IMRT alone for intermediate T-stage oropharyngeal carcinoma. Strahlenther Onkol 186:489-495

17. Inoue T, Oh RJ, Shiomi H (2011) New approach for treatment of vertebral metastases using intensity-modulated radiotherapy. Strahlenther Onkol 187:108-113 
18. International Commission on Radiation Units and Measurements (1999) ICRU Report 62: Prescribing, recording, and reporting photon beam therapy (Supplement to ICRU Report 50). ICRU, Bethesda, MD

19. Jacob V, Bayer W, Astner ST et al (2010) A planning comparison of dynamic IMRT for different collimator leaf thicknesses with helical tomotherapy and RapidArc for prostate and head and neck tumors. Strahlenther Onkol 186:502-510

20. Jones A (1964) Transient radiation myelopathy. (with reference to Lhermitte's sign of electrical paraesthesia). Br J Riadol 37:727-744

21. Kachandani R, Howe JG (1982) Lhermitte's sign in multiple sclerosis: a clinical survey and review of the literature. J Neurol Neurosurg Psychiatry 45:308-312

22. Kirkpatrick JP, Kogel AJ van der, Schultheiss TE (2010) Radiation Dose - Volume Effects in the spinal cord. http://www.sciencedirect.com/science/ journal/03603016. Int J Radiat Oncol Biol Phys 76(Suppl 1):42-49.

23. Kong FM, Pan C, Eisbruch A et al (2007) Physical models and simpler dosimetric descriptors of radiation late toxicity. Semin Radiat Oncol 17:108-120

24. Langendijk JA, Slotman BJ, Waal I van der et al (2005) Risk-group definition by recursive partitioning analysis of patients with squamous cell head and neck carcinoma treated with surgery and postoperative radiotherapy. Cancer 104:14081417

25. Lengyel Z, Rékó G, Majtényi K et al (2003) Autopsy verifies demyelination and lack of vascular damage in partially reversible radiation myelopathy. Spinal Cord 41:577-585

26. Leung WM, Tsang NM, Chang FT et al (2005) Lhermitte's sign among nasopharyngeal cancer patients after radiotherapy. Head Neck 27:187-194

27. Lhermitte J, Bollak J, Nicolas M (1924) Les douleurs a type de decharge electrique consecutives a la flexion cephalique dans la sclerose en plaques. Un cas de forme sensitive de la sclerose multiple. Rev Neural 39:56-62

28. Lossos A, Siegal T (1996) Electric shock-lick sensations in 42 cancer patients: clinical characteristics and distinct etiologies. J Neurooncol 29:174-181

29. Marcus RB Jr, Million RR (1990) The incidence of myelitis after irradiation of the cervical spinal cord. Int J Radiat Oncol Biol Phys 19:3-8

30. Marie P, Chatelin C (1917) Sur certains symptomes vraisemblablement d'origine radiculaire chez les blessés du crâne. Rev Neural 31:336

31. McCunniff AJ, Liang MJ (1989) Radiation tolerance of the cervical spinal cord. Int J Radiat Oncol Biol Phys 16:675-678

32. Reagan TJ, Thomas JE, Colby MY (1968) Chronic progressive radiation myelopathy. JAMA 203:106110

33. Schultheiss TE (2008) The radiation dose-response of the human spinal cord. Int J Radiat Oncol Biol Phys 45:174-175

34. Van der Kogel AJ (1993) Dose-volume effects in the spinal cord. Radiother Oncol 29:105-109

35. Vitzthum HE, Dalitz K (2007) Analysis of five specific scores for cervical spondylogenic myelopathy. Eur Spine J 16:2096-2103 